\title{
Lockdown Impact on Particulate Matter and Role of Meteorological Parameters in the Transmission of Covid-19
}

\author{
Manish Sharma*† and Pargin Bangotra* \\ *Satellite Remote Sensing Group, Department of Physics, School of Basic Sciences and Research, Sharda University, \\ Greater Noida, India \\ †Corresponding author: Manish Sharma; manish.sharma@sharda.ac.in
}

Nat. Env. \& Poll. Tech. Website: www.neptjournal.com

Received: 01-08-2020

Revised: $05-09-2020$

Accepted: 08-10-2020

Key Words:

COVID 19

Particulate matter

Meteorological parameters

Lockdown impact

\begin{abstract}
The coronavirus disease (COVID-19) was first noticed over Wuhan, China during December 2019. The spreading characteristics of COVID-19 infection from one person to another are resulting in a growing number of infected cases and created massive stresses across the world. The rapid dissemination of COVID-19 infection declares it as a pandemic. In India, till the mid of May 2020, there were around 75,048 confirm with 2440 number of death cases, specifically due to COVID-19. To break the chain of COVID-19, the Government of India had decided to implement the lockdown, first implemented on $23^{\text {rd }}$ March 2020. Some of the significant benefits of lockdown resulted in the reduction in atmospheric pollutants of the cities across the world. The study is based on the fine and coarse particulate matters (PM) data corresponding to before lockdown and during lockdown periods. The efforts were made over Delhi (DEL) and one of the neighbouring cities, i.e. Gurgaon (GW) considering the duration $1^{\text {st }}$ January 2020 to $15^{\text {th }}$ May 2020 to understand the impact of lockdown on the particulate matter, i.e. PM $\left(P_{1.0}\right.$, $\mathrm{PM}_{2.5}$ and $\mathrm{PM}_{10}$ ). Our investigation shows the decline in $\mathrm{PM}$ concentration during the lockdown period. The impact of COVID-19 pandemic resulted in the rapid increase in the number of COVID-19 cases in DEL, India, and the inhabitants of about 14 million people. The significance of the particulate matter, temperature $\left({ }^{\circ} \mathrm{C}\right)$ and relative humidity (\%) on the dispersal of COVID-19 virus and its association to the total number of cases (TC), active cases (AC), recovered cases (RC) and death cases (DC) with special reference to DEL were also discussed.
\end{abstract}

\section{INTRODUCTION}

In the existing scenario, the whole world is at the risk of the widespread global infection, i.e. COVID-19 declared as pandemic (WHO 2020) that affected more than 208 countries (Singh et al. 2020). According to the recent study conducted by Jain et al. (2020), there were approximately 4,369,933 COVID-19 cases all over the world out of which $98 \%$ were suffering from mild, $2 \%$ with a severe infection while $15 \%$ patient could not survive. The first case of the novel coronavirus, i.e. COVID-19 was initially reported in Wuhan city, China in December 2019 and after a few weeks, it started to progressively spread across bordering countries. As per the medical reports, COVID-19 has a severe impact on the respiratory system causing a range of breathing problems, from mild to critical and, more dangerous for the people's previous history of bronchitis, Chronic Obstructive Pulmonary Disease (COPD), heart disease, and diabetes. As per the World Health Organization (WHO), the people having age above 60 years, and children less than 10 years are severely affected by coronavirus (Donnelly et al. 2003). As per the medical experts, this type of disease is a bit similar to severe acute respiratory syndrome (SARS), mostly spread through the droplets, hand contact or some times by indirect contact also, but still, the exact reasons of the medium of transmission or the routes of transmission could not be recognized.

In India, till 13th May 2020, there were around 75,048 confirmed with 2440 number of death cases (MoHFW 2020). By seeing the criticality of this infection and its fast spread, the Government of India has decided to implement the lockdown in different phases which was first implemented on 23rd March 2020. As a preventive measure, various activities and operations related to the social gathering, travel, industries operations, transport including all three modes, commercials, construction, restaurants except the limited essential services like groceries, milk, fruits and vegetable, medicines, etc. were restricted. However, one of the positive impacts which has been observed in many cities and countries including China, Brazil, Barcelona, New York, Los Angeles, Zaragoza, Rome, Dubai, India, Beijing, Shanghai, etc., was the reduction of the pollutants during the period of lockdown (Bao \& Zhang 2020, Saadat et al. 2020, Singh et al. 2020). $\mathrm{Xu}$ et al. (2020) reported the deterioration in the levels of 
pollutants like $\mathrm{PM}_{2.5}, \mathrm{PM}_{10}, \mathrm{SO}_{2}, \mathrm{CO}$, and $\mathrm{NO}_{2}$ during the lockdown period over China. With the various air pollution monitoring stations, the improvement in air quality was also observed in most of the Indian cities during the lockdown period (http://www.cpcbenvis.nic.in/). Before the lockdown, the pollutant level in most Indian cities was at very high (Aggarwal \& Jain 2015, Kumar et al. 2013, WHO 2018).

The earlier study demonstrated the noticeable effect of meteorological parameters especially surface air temperature and relative humidity on particulate matters (Wang et al. 2020). Wu et al. (2020) are also in close agreement of the association between air quality and COVID-19 cases in China. Air pollution measured as particulate matter (PM) has also been shown to be detrimental to human health (Cohen et al. 2005, Donaldson et al. 2001) and lead to increased mortality rates (Dockery et al. 1993, Hales et al. 2010). Various pollutants have been included to define the air quality index, some of them are $\mathrm{CO}$, ozone, $\mathrm{SO}_{2}, \mathrm{NO}_{2}, \mathrm{NH}_{3}, \mathrm{~Pb}, \mathrm{PM}_{2.5}$ and $\mathrm{PM}_{10}$ (NAAQS). However, the most accountable pollutants responsible for poor air quality indexes in India are currently $\mathrm{PM}_{2.5}$ and $\mathrm{PM}_{10}$.

Saksena \& Dayal (2000), in their study over DEL, considered PM as one of the hazardous pollutants responsible for chronic bronchitis, whereas, Goyal (2003) found it accountable for asthma. Therefore, considering the criticality of PM and the current lockdown situation, we have analysed the fine $\left(\mathrm{PM}_{1.0}\right.$ and $\left.\mathrm{PM}_{2.5}\right)$ and coarse $\left(\mathrm{PM}_{10}\right) \mathrm{PM}$ data for seven different places of Delhi (DEL) and Gurugram also known as Gurgaon (GW), India. Gurgaon is a city situated in the southwest of
New Delhi. The 24 hours daily mean concentrations of PM $\left(\mathrm{PM}_{1.0}, \mathrm{PM}_{2.5}\right.$ and $\left.\mathrm{PM}_{10}\right)$ were analysed for the different sites over DEL, i.e. IIT-Delhi (IIT-DEL), Greater Kailash (GK), Lodhi Road (LR), Mahant Gurmukh Singh (MGS), Ramjas colony (RJ), Shantipath (SP), US Embassy (USE) and Gurgaon $(\mathrm{GW})$ together with the corresponding temperature $\left(\mathrm{T}^{\circ} \mathrm{C}\right)$ and relative humidity (RH \%) for the duration from 1st January 2020 to 15th May 2020. The resulting daily averages corresponding to the above locations were analysed and compared for before (1st January 2020 - 22nd March 2020) and during lockdown (23rd March 2020-15th May 2020) period. As the optimized $\mathrm{T}\left({ }^{\circ} \mathrm{C}\right)$ and $\mathrm{RH}(\%)$ support the droplet stability in the local environment which may be favourable for the widespread transmission of the virus (Chen et al. 2020). As per the study conducted over different cities of Italy and China, it was noticed that the association between the high frequency of corona cases/mortality and the high level of atmospheric pollutants persistently for over four years (Down to Earth ). The efforts were also made over DEL to understand the linkage between PM, T $\left({ }^{\circ} \mathrm{C}\right)$, and $\mathrm{RH}(\%)$ and their synergic effect on COVID-19 cases corresponding to the total number of cases (TC), active cases (AC), recovered cases (RC) and death cases (DC) by considering the available data for period 1st April 2020 to 15th May 2020.

\section{DATA AND ANALYSIS TECHNIQUES}

The present study examines the effect of lockdown on the air quality of Delhi (DEL) and Gurgaon (GW), India (Fig. 1). The data related to major pollutants, i.e. $\mathrm{PM}$ of size $\leq 2.5$

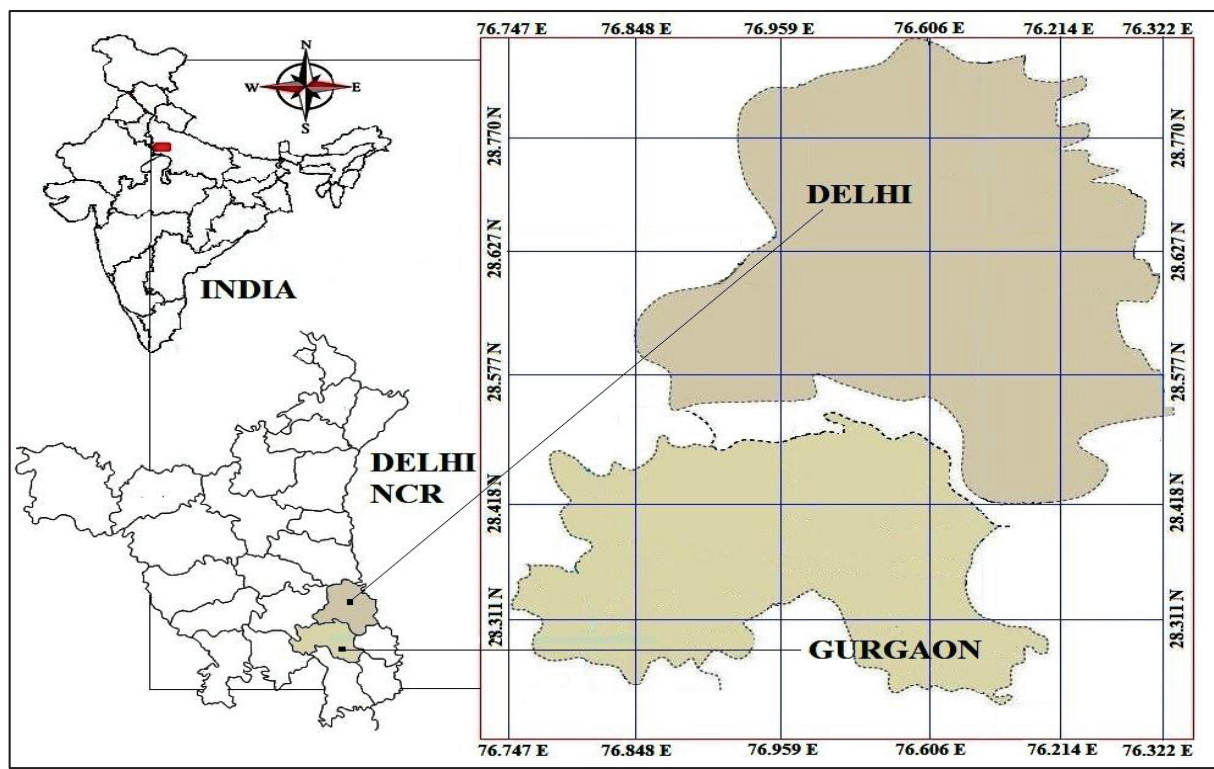

Fig. 1: Map of the studied region. 
$\mu \mathrm{m}\left(\mathrm{PM}_{2.5}\right), \leq 10 \mu \mathrm{m}\left(\mathrm{PM}_{10}\right)$ and $\leq 1.0\left(\mathrm{PM}_{1.0}\right)$ along with meteorological parameters, i.e. T $\left({ }^{\circ} \mathrm{C}\right), \mathrm{RH}(\%)$ were downloaded through the freely available data source, i.e. Purple Air Sensors (https://www.purpleair.com). The PurpleAir sensors are an "Internet of things" (IoT) air quality sensor or particulate sensor consisting of a network of elements. PurpleAir uses PMS5003 and PMS1003 laser particle counters. These sensors count suspended particles in sizes of $0.3,0.5,1.0$, 2.5, 5.0 and $10 \mu \mathrm{m}$. These particle counts are processed by the sensor using a complex algorithm to calculate the $\mathrm{PM}_{1.0}$, $\mathrm{PM}_{2.5}$ and mass concentration in $\mu \mathrm{g} . \mathrm{m}^{-3}$.

The continuous 24-hour average PM with associated T $\left({ }^{\circ} \mathrm{C}\right)$ and $\mathrm{RH}(\%)$ data was procured for the period 1 st January 2020 to 15 th May 2020. The procured data cover seven different sites over Delhi, i.e. IIT-DEL, GK, LR, MGS, RJ, SP and USE, and two locations over GW (Fig. $1)$. In the case of the analysis over DEL and GW, the combined averages of all locations were taken. The data corresponding to $\mathrm{TC}$ as well as $\mathrm{RC}$ was collected from the source of New Delhi Television Limited (NDTV), an Indian television media company. (https://www.ndtv.com/coronavirus?pfrom=home-mainnavgation). To calculate the 2-tailed Bivariate Pearson correlations among PM, T $\left({ }^{\circ} \mathrm{C}\right), \mathrm{RH}(\%)$, TC, AC, RC and DC, the statistical analysis model Statistical Package for the Social Sciences (SPSS) was used.

\section{RESULTS AND DISCUSSION}

This section examines the variation in the mean concentration of PM associated to size 1 micron, 2.5 microns and 10 microns commonly recognized as $\mathrm{PM}_{1.0}, \mathrm{PM}_{2.5}$ and $\mathrm{PM}_{10}$, over DEL and GW, Influence of Meteorology on PM and its association to TC and RC associated to COVID-19.

\section{Distribution of PM}

The significant dissimilarity appears for fine $\left(\mathrm{PM}_{1.0}, \mathrm{PM}_{2.5}\right)$ and coarse $\left(\mathrm{PM}_{10}\right)$ over DEL and $\mathrm{GW}$ in the box and whiskers charts view (Fig. 2).

The boxes here correspond to $50 \%$ of the distribution of the values (from $25 \%$ to $75 \%$ ), while the square and line within the boxes indicate the mean and median values, respectively. The "x" and "-" symbols correspond to 1\%/99\% and $\mathrm{min} / \mathrm{max}$ values, respectively. The dissimilar dispersal can be visible clearly from the distribution pattern of PM concentration $\left(\mathrm{PM}_{1.0}, \mathrm{PM}_{2.5}\right.$ and $\left.\mathrm{PM}_{10}\right)$ in the above two sites during the period $1^{\text {st }}$ January 2020 to $15^{\text {th }}$ May 2020. It was found the median PM concentration of $56.10 \mu \mathrm{g} \cdot \mathrm{m}^{-3}\left(\mathrm{PM}_{1.0}\right)$, $85.72 \mu \mathrm{g} . \mathrm{m}^{-3}\left(\mathrm{PM}_{2.5}\right)$ and $96.03 \mu \mathrm{g} . \mathrm{m}^{-3}\left(\mathrm{PM}_{10}\right)$ over DEL while lower median concentration of $29.66 \mu \mathrm{g} \cdot \mathrm{m}^{-3}\left(\mathrm{PM}_{1.0}\right), 44.62$ $\mu \mathrm{g} . \mathrm{m}^{-3}\left(\mathrm{PM}_{2.5}\right)$ and $48.22 \mu \mathrm{g} . \mathrm{m}^{-3}\left(\mathrm{PM}_{10}\right)$ was observed over GW. The higher mean PM concentration of $69.22 \mu \mathrm{g} . \mathrm{m}^{-3}$

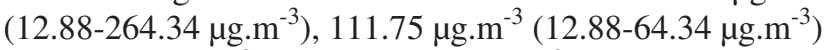
and $127.61 \mu \mathrm{g} . \mathrm{m}^{-3}\left(20.94-559.78 \mu \mathrm{g} . \mathrm{m}^{-3}\right)$ related to $\mathrm{PM}_{1.0}$, $\mathrm{PM}_{2.5}$ and $\mathrm{PM}_{10}$, respectively were observed over DEL. It was noticed that the low mean concentration of PM $\left(\mathrm{PM}_{1.0}\right.$, $\mathrm{PM}_{2.5}$ and $\mathrm{PM}_{10}$ ) over the site $\mathrm{GW}$ show better air quality as compare to DEL. All of the sizes of PM were exhibited dissimilar concentration that indicates the diverse sources over both the locations, i.e. DEL and GW. The higher mean concentration and prominent characteristic of $\mathrm{PM}_{2.5}$ and $\mathrm{PM}_{10}$ indicated in Box plot (Fig. 2), suggest road traffic (Mahato et al. 2020, Kumar et al. 2017) as well as industries, power plants and domestic emissions (Sahu et al. 2011a, Guttikunda et al. 2013) as the prime responsible factors.

In trend analysis (Figs. 3a \& 3b), covering entire duration, i.e. $1^{\text {st }}$ January 2020 to $15^{\text {th }}$ May $2020, \mathrm{PM}_{10}$ exhibit a higher mean concentration of $127.61 \mu \mathrm{g} . \mathrm{m}^{-3}$ (DEL) and $57.53 \mu \mathrm{g} . \mathrm{m}^{-3}$ $(\mathrm{GW})$, whereas $\mathrm{PM}_{1.0}$ and $\mathrm{PM}_{2.5}$, illustrate the mean concentration of $69.22 \mu \mathrm{g} . \mathrm{m}^{-3}$ (DEL), $34.20 \mu \mathrm{g} . \mathrm{m}^{-3}(\mathrm{GW})$ and 111.75 $\mu \mathrm{g} . \mathrm{m}^{-3}$ (DEL) and $53.10 \mu \mathrm{g} \cdot \mathrm{m}^{-3}(\mathrm{GW})$, respectively. The higher PM concentration during this period, evidently suggests the vehicular emission, industrial emission, and other forms of combustion process as the major sources of pollutants. After the execution of comprehensive lockdown through

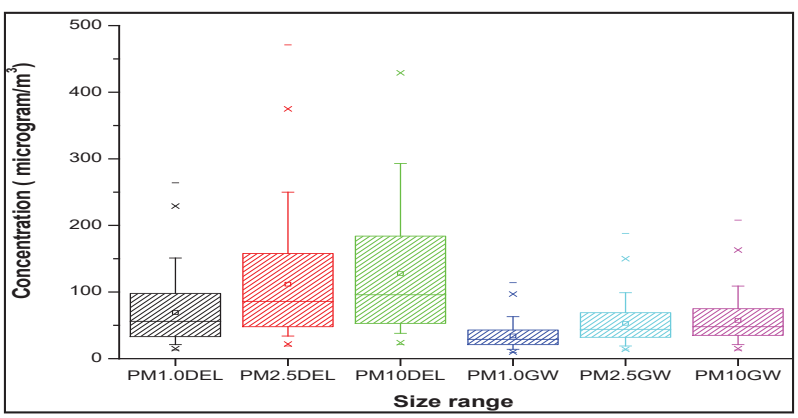

Fig. 2 Boxplots of daily concentrations of analysed pollutants over Delhi and Gurgaon; the median is shown by the middle line of the box. Concentrations are expressed in $\mu \mathrm{g} . \mathrm{m}^{-3}$ for $\mathrm{PM}_{1.0}, \mathrm{PM}_{2.5}$ and $\mathrm{PM}_{10}$. 
restricting various activities and operations related to social assembly, travel, industries operations, and transport started from $23^{\text {rd }}$ March 2020, PM mass concentration in DEL (Fig. 3a), and GW (Fig. 3b) were significantly declined. Before the lockdown, it was noticed that the PM concentration in DEL as $94.72 \mu \mathrm{g} . \mathrm{m}^{-3}\left(\mathrm{PM}_{1.0}\right), 155.45 \mu \mathrm{g} . \mathrm{m}^{-3}\left(\mathrm{PM}_{2.5}\right)$ and $178.88 \mu \mathrm{g} . \mathrm{m}^{-3}\left(\mathrm{PM}_{10}\right)$ that drastically reduced to $30.96 \mu \mathrm{g} . \mathrm{m}^{-}$ ${ }^{3}, 46.12 \mu \mathrm{g} . \mathrm{m}^{-3}$ and $50.69 \mu \mathrm{g} . \mathrm{m}^{-3}$ by the percentage decrease of $67.31,70.29$ and 71.66 , respectively due to the result of the lockdown. The significant decline in the concentration of PM, clearly confirms the influence of the transport and traffic movement in the air quality of DEL.

Before lockdown, low PM concentration has been observed corresponding to $\mathrm{PM}_{1.0}\left(42.29 \mu \mathrm{g} \cdot \mathrm{m}^{-3}\right), \mathrm{PM}_{2.5}(66.82$ $\mu \mathrm{g} . \mathrm{m}^{-3}$ ), and $\mathrm{PM}_{10}\left(72.62 \mu \mathrm{g} . \mathrm{m}^{-3}\right.$ ), in GW (Fig. 2b) as compared to DEL. The observed PM concentration $\left(\mathrm{PM}_{2.5}\right.$ and $\mathrm{PM}_{10}$ ) was slightly towards the higher side of the prescribed limit given by NAAQS (http://cpcb.nic.in/airquality-Standard). The tremendous decline of $48.21 \%, 51.82 \%$ and 52.45 $\%$ in $\mathrm{PM}_{1.0}\left(21.90 \mu \mathrm{g} \cdot \mathrm{m}^{-3}\right), \mathrm{PM}_{2.5}\left(32.19 \mu \mathrm{g} \cdot \mathrm{m}^{-3}\right)$ and $(34.52$ $\mu \mathrm{g} . \mathrm{m}^{-3}$ ) were witnessed the impact of lockdown over GW. The analysis related to before and after lockdown noticeably exposed a significant decline in the concentration of PM pollutants during lockdown (23 $3^{\text {rd }}$ March- $15^{\text {th }}$ May 2020) by strictly follow-up. Due to holdup of all type of movements, industrial emission and transportation on the road, the fine $\left(\mathrm{PM}_{1.0}\right.$ and $\left.\mathrm{PM}_{2.5}\right)$ and coarse $\left(\mathrm{PM}_{10}\right)$ particulate were significantly reduced over both of the locations (DEL and GW) and approached within the limit of NAAQS $\left(\mathrm{PM}_{2.5}=60\right.$ $\mu \mathrm{g} . \mathrm{m}^{-3}, \mathrm{PM}_{10}=100 \mu \mathrm{g} \cdot \mathrm{m}^{-3}$, based on 24-hours average (Jain et al. 2020) demonstrating the noticeable improvement in air quality. The significant decrease in atmospheric pollution attributed to transportation and industrial emissions over Beijing, Shanghai, Guangzhou and Wuhan cities were also observed during the corona pandemic (Wang et al. 2020).

\section{Influence of Meteorology on PM}

The previous studies demonstrated the effect of meteorological variables which has a major impact on air quality (Espinosa et al. 2004, Karar \& Gupta 2006). The complete cycle of the formation of secondary pollutants has a great association with the pollutant release rate into the air from the origin, wind speed, turbulence level, air temperature, and precipitation (Bhaskar et al. 2010). Generally, $\mathrm{T}\left({ }^{\circ} \mathrm{C}\right)$ has substantial involvement in the air quality of the province, therefore, correlation analysis by considering the period of $1^{\text {st }}$ March $2020-15^{\text {th }}$ May 2020 between PM concentrations and $\mathrm{T}\left({ }^{\circ} \mathrm{C}\right)$ for the site DEL (Fig. 4) and GW (Fig. 5) were
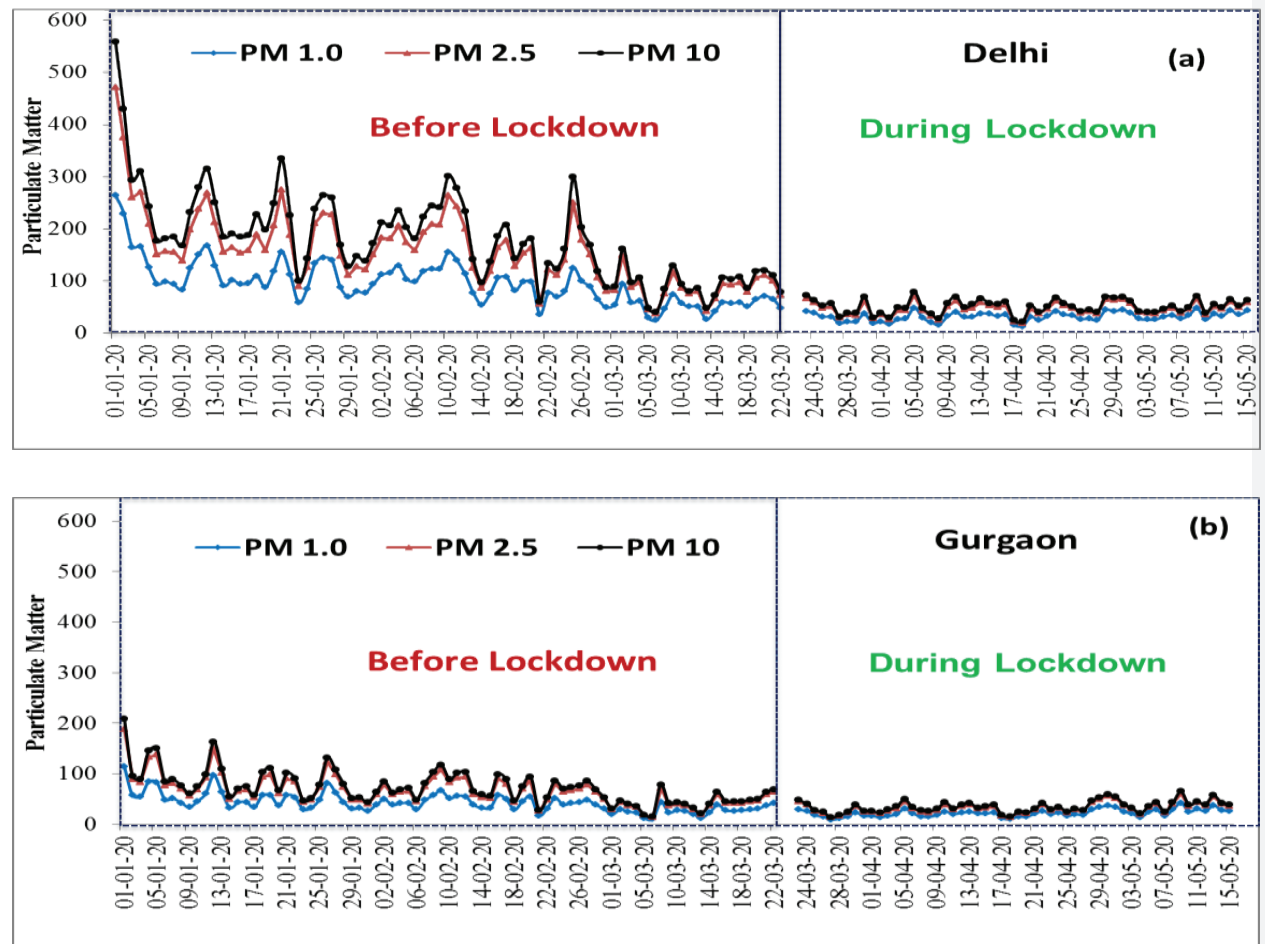

Fig. 3 (a, b). Trend analysis showing the effect of lockdown period on particulate matter in Delhi (a) and Gurgaon (b). 
studied to understand the role of $\mathrm{T}\left({ }^{\circ} \mathrm{C}\right)$.

There was a significant negative correlation between $\mathrm{T}$ $\left({ }^{\circ} \mathrm{C}\right)$ and $\mathrm{PM}_{1.0}(0.72), \mathrm{PM}_{2.5}(0.73)$ and $\mathrm{PM}_{10}(0.73)$ in DEL while over $\mathrm{GW}$, it was found to be $0.54\left(\mathrm{PM}_{1.0}\right), 0.58\left(\mathrm{PM}_{2.5}\right)$ and $0.25\left(\mathrm{PM}_{10}\right)$. In the associated Fig. 4 and Fig. 5, the red, green and black dots indicate the data corresponding to $\mathrm{PM}_{1.0}, \mathrm{PM}_{2.5}$ and $\mathrm{PM}_{10}$, respectively. The regression analysis reveals a significant negative correlation $(\mathrm{r})$ of $\mathrm{T}\left({ }^{\circ} \mathrm{C}\right)$ with PM in DEL whereas GW has a low negative correlation of 0.25 with $\mathrm{PM}_{10}$. The regression slope obtained over DEL was $-0.09\left(\mathrm{PM}_{1.0}\right),-0.05\left(\mathrm{PM}_{2.5}\right)$ and $-0.04\left(\mathrm{PM}_{10}\right)$ which has the similar pattern as followed over $\mathrm{GW}$ with regression slope $-0.16\left(\mathrm{PM}_{1.0}\right),-0.11\left(\mathrm{PM}_{2.5}\right)$ and $-0.01\left(\mathrm{PM}_{10}\right)$, respectively. The complete period of observation indicates the declining characteristics of PM concentrations on the increase of the $\mathrm{T}\left({ }^{\circ} \mathrm{C}\right)$.

\section{PM Over Different Locations of DEL and GW}

As long-range transport and dust also have a significant contribution to the accumulation or dispersion of pollutants at urban sites (Arif et al. 2018). Further, the concentration of $\mathrm{PM}_{1.0}, \mathrm{PM}_{2.5}$ and $\mathrm{PM}_{10}$ for seven different locations of DEL and GW were analysed and impressed in the box and whisker plot to distinguish the possible impact of lockdown (Fig. 6a-c).

Before lockdown and during the lockdown period of the study have been distinguished by the letter B and A, respectively. Before lockdown, the mean concentration of $\mathrm{PM}_{1.0}$ and $\mathrm{PM}_{2.5}$ over IIT-DEL, GK, LR, MGS, RJ, SP and USE were $89.29 \pm 45.51 \mu \mathrm{g} . \mathrm{m}^{-3}, 57.07 \pm 32.70 \mu \mathrm{g} . \mathrm{m}^{-3}, 90.01 \pm 40.72 \mu \mathrm{g} . \mathrm{m}^{-}$ ${ }^{3}, 70.35 \pm 28.33 \mu \mathrm{g} \cdot \mathrm{m}^{-3}, 133.18 \pm 68.15 \mu \mathrm{g} . \mathrm{m}^{-3}, 97.53 \pm 49.39$ $\mu \mathrm{g} . \mathrm{m}^{-3}, 121.31 \pm 54.03 \mu \mathrm{g} \cdot \mathrm{m}^{-3}$ and $146.67 \pm 78.63 \mu \mathrm{g} \cdot \mathrm{m}^{-3}, 85.04$ $\pm 51.02 \mu \mathrm{g} . \mathrm{m}^{-3}, 162.04 \pm 91.42 \mu \mathrm{g} . \mathrm{m}^{-3}, 124.75 \pm 57.26 \mu \mathrm{g} . \mathrm{m}^{-}$ ${ }^{3}, 218.38 \pm 144.20 \mu \mathrm{g} \cdot \mathrm{m}^{-3}, 163 \pm 88.94 \mu \mathrm{g} . \mathrm{m}^{-3}, 191.09 \pm 94.03$ $\mu \mathrm{g} . \mathrm{m}^{-3}$, respectively (Fig. 5a and Fig. 5b). However, the mean concentration of $\mathrm{PM}_{1.0}$ in the above said locations was $166 \pm 89.47 \mu \mathrm{g} . \mathrm{m}^{-3}, 103.33 \pm 60.19 \mu \mathrm{g} . \mathrm{m}^{-3}, 187.32 \pm 116.52$ $\mu \mathrm{g} . \mathrm{m}^{-3}, 134.78 \pm 63.75 \mu \mathrm{g} . \mathrm{m}^{-3}, 283.46 \pm 161.89 \mu \mathrm{g} . \mathrm{m}^{-3}$,

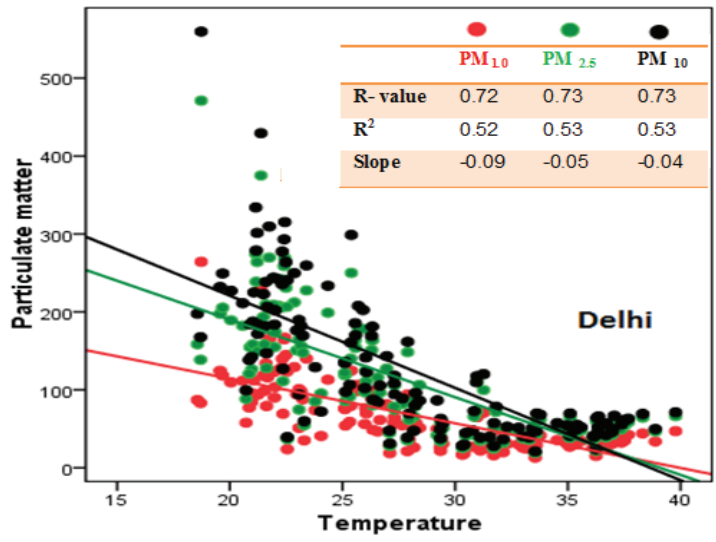

Fig. 4: Scatter plot among $\mathrm{PM}_{1.0}, \mathrm{PM}_{2.5}$ and $\mathrm{PM}_{10}$ and $\mathrm{T}\left({ }^{\circ} \mathrm{C}\right)$ over DEL.

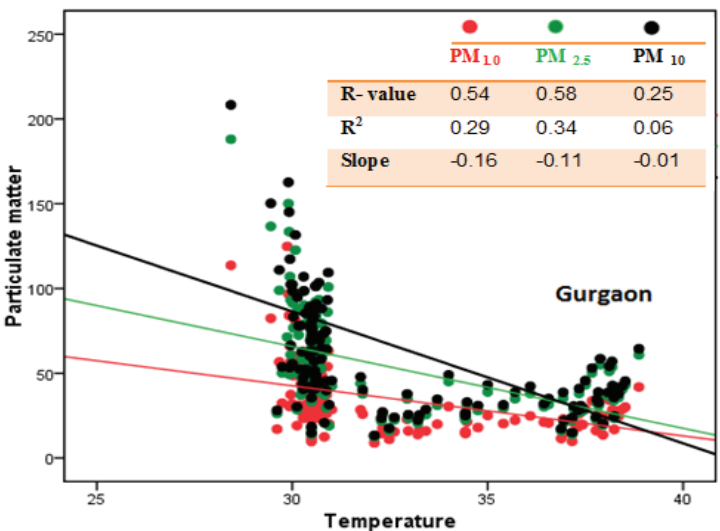

Fig. 5: Scatter plot among $\mathrm{PM}_{1.0}, \mathrm{PM}_{2.5}$ and $\mathrm{PM}_{10}$ and $\mathrm{T}\left({ }^{\circ} \mathrm{C}\right)$ over $\mathrm{GW}$. 

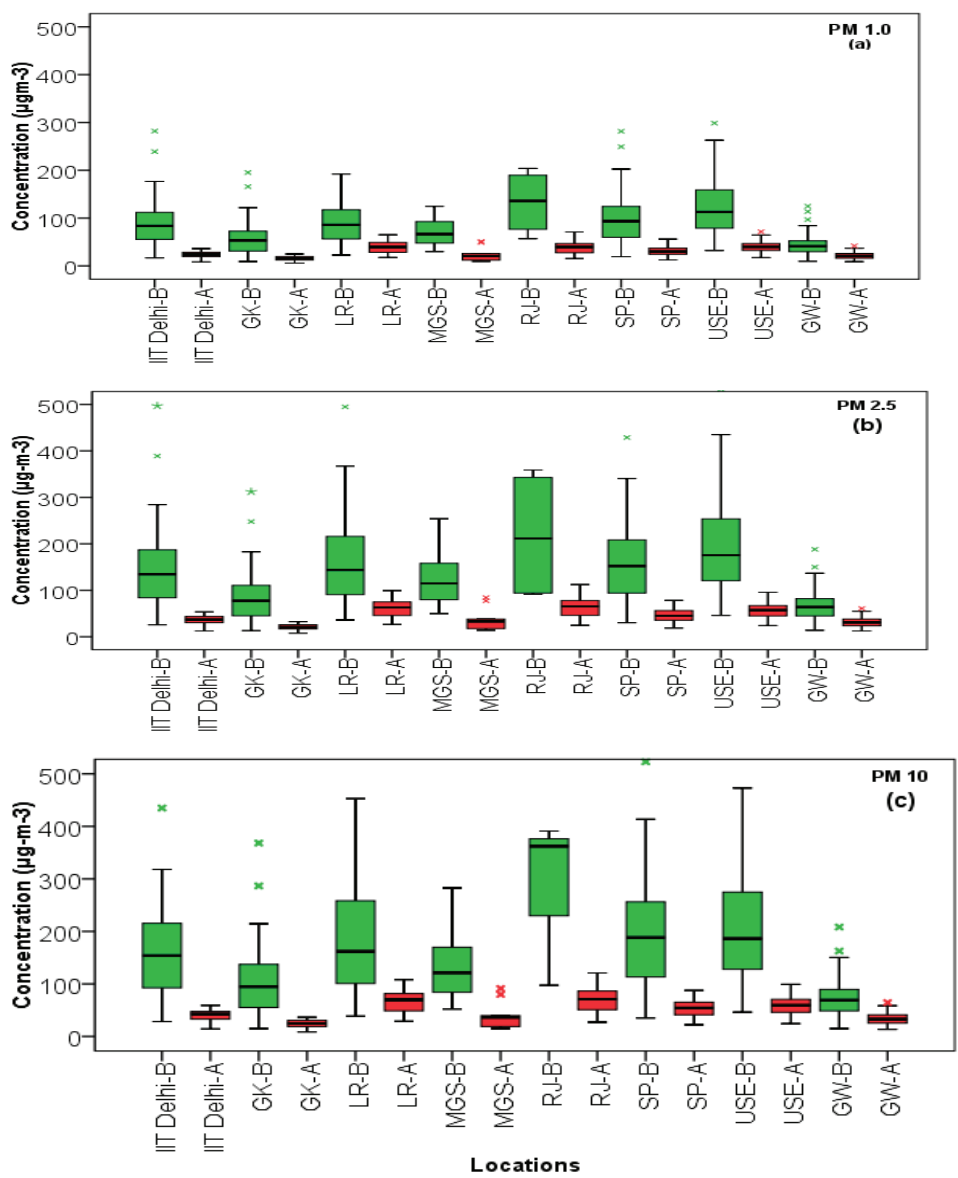

Fig.6. Boxplots of daily concentrations of analysed pollutants over different locations of Delhi and Gurgaon; the median is shown by the middle line of the box. Concentrations are expressed in $\mu \mathrm{g} \cdot \mathrm{m}^{-3}$ for $\mathrm{PM}_{1.0}(\mathrm{a}), \mathrm{PM}_{2.5}$ (b) and $\mathrm{PM}_{10}$ (c). (Letter " $\mathrm{B}$ " and " $\mathrm{A}$ " represent the boxes related to before lockdown and during lockdown respectively).

$200.83 \pm 112.21 \mu \mathrm{g} \cdot \mathrm{m}^{-3}, 205 \pm 105.07 \mu \mathrm{g} \cdot \mathrm{m}^{-3}$, respectively as depicted in Fig. 6c.

The GW region was observed the lower PM concentration, i.e. $43.31 \pm 20.25 \mu \mathrm{g} . \mathrm{m}^{-3}\left(\mathrm{PM}_{1.0}\right), 66.55 \pm 29.94 \mu \mathrm{g} . \mathrm{m}^{-3}$ $\left(\mathrm{PM}_{2.5}\right)$, and $72.63 \pm 33.10 \mu \mathrm{g} \cdot \mathrm{m}^{-3}\left(\mathrm{PM}_{10}\right)$ as compared to DEL during the span of before lockdown. The average $\mathrm{PM}_{2.5}$ and $\mathrm{PM}_{10}$ concentrations over the different study sites of DEL and $\mathrm{GW}$ regions were at higher side than the given limit of NAAQS $\left(\mathrm{PM}_{2.5}=40 \mu \mathrm{g} \cdot \mathrm{m}^{-3}\right)$ and $\left.\mathrm{PM}_{10}=60 \mu \mathrm{g} \cdot \mathrm{m}^{-3}\right)($ Jain et al. 2020). Before the lockdown situation, the highest $\mathrm{PM}_{1.0}$ values were found over the RJ showing mean of 133.18 $\mu \mathrm{g} . \mathrm{m}^{-3}$ and is followed by USE, SP, LR, IIT, MGS and GW, respectively. The high interquartile range (RJ, USE, SP and $\mathrm{LR}$ ) suggests that $\mathrm{PM}_{10}$ hold quite different concentration demonstrating the large spread (56.95-203.85 $\left.\mu \mathrm{g} . \mathrm{m}^{-3}\right)$. The large upper whisker over the location IIT-DEL, SP and USE show that the $\mathrm{PM}_{1.0}$ concentration varies amongst the most positive quartile group. The upper parts of the scale, i.e. positive quartile group corresponding to almost all locations except RJ shows the pronounced variability in the concentration of $\mathrm{PM}_{1.0}$, but in the case of the least positive quartile group, the concentration spread is relatively less. However, the box plots associated with the before lockdown period, show large concentration distributions of $\mathrm{PM}_{1.0}$ whereas the box plot accompanying during lockdown shows the slight dispersion that illustrates the extreme decline in the concentration of $\mathrm{PM}_{1.0}$.

As per the previous studies, $\mathrm{PM}_{2.5}$ comprises numerous unsafe constituents, which may enter into the lungs through the respiratory tract and hazardous to the human health, mainly to children and the elderly people (Daoru et al. 2018). The previously conducted study, expose the particulate matter as one of the prime reasons behind the destructive consequence on the human respiratory system by emphasizing to take 
recurrent medical prescription (Anderson et al. 2012). The dissemination and variability of $\mathrm{PM}_{2.5}$ concentration have been summarized in box plots as depicted in Fig. 6(b). The highest mean concentration of fine particulate matter $\mathrm{PM}_{2.5}$ $\left(218.37 \mu \mathrm{g} . \mathrm{m}^{-3}\right)$ was observed over RJ during before lockdown period and $63.41 \mu \mathrm{g} . \mathrm{m}^{-3}$ during the lockdown period. The extremely upper and lower whiskers (before lockdown) demonstrate the case of least quartile that corresponds to less pronounced behaviour of $\mathrm{PM}_{2.5}$ concentration due to the less number of data (4 days) over RJ region. The localities LR, SP and USE unveil the large upper whisker and show the noticeable inconsistency in the concentration of $\mathrm{PM}_{2.5}$.

As compared to the DEL region, the GW region (Fig. 6b) elucidate the low mean $\mathrm{PM}_{2.5}$ concentration monitoring data, i.e. $73.51 \mu \mathrm{g} . \mathrm{m}^{-3}\left(13.98 \mu \mathrm{g} . \mathrm{m}^{-3}-188.04 \mu \mathrm{g} . \mathrm{m}^{-3}\right)$ associated to prior lockdown (GW-B) that drastically reduced to $31.97 \mu \mathrm{g} . \mathrm{m}^{-3}\left(12 \mu \mathrm{g} \cdot \mathrm{m}^{-3}-60.83 \mu \mathrm{g} . \mathrm{m}^{-3}\right)$ due to the impact of lockdown (GW-A). The lockdown impact was responsible for the sudden fall in $\mathrm{PM}_{2.5}$ concentrations due to nationwide restriction on transport movement and industrial units that were associated with the emission of primary pollutants into the vicinity. Before the lockdown period, the corresponding locations of DEL and GW were high $\mathrm{PM}_{2.5}$ concentration which supports the finding of ambient $\mathrm{PM}_{2.5}$ concentrations greater than $60 \mu \mathrm{g} . \mathrm{m}^{-3}$ over New Delhi (Singh et al. 2011, Tiwari et al. 2014). This might be due to the location of the site that is close to traffic and residential pollution sources (Gulia et al. 2018, Kumar et al. 2017). As per the above findings, a very diverse pattern of PM concentration has been observed in the studied region. Fig. 6(c) exposes the mean concentration of $\mathrm{PM}_{10}$ by showing the highest value over RJ $\left(283.46 \mu \mathrm{g} . \mathrm{m}^{-3}\right)$ trailed by USE $\left(205.82 \mu \mathrm{g} . \mathrm{m}^{-3}\right)$ and
SP $\left(200.83 \mu \mathrm{g} . \mathrm{m}^{-3}\right)$ associated to before lockdown period that further started to deteriorate to $69.36 \mu \mathrm{g} \cdot \mathrm{m}^{-3}$ (RJ), 58.64 $\mu \mathrm{g} . \mathrm{m}^{-3}$ (USE) and $53.59 \mu \mathrm{g} \cdot \mathrm{m}^{-3}$ (SP) due to the lockdown effect. The location GW shows the mean concentration of $72.63 \mu \mathrm{g} . \mathrm{m}^{-3}$ (before lockdown) and $34.28 \mu \mathrm{g} . \mathrm{m}^{-3}$ (during lockdown) and both are very close to the prescribed limit of $60 \mu \mathrm{g} . \mathrm{m}^{-3}$ given by NAAQS.

\section{COVID-19 and Associated Factor}

DEL has been regarded as one of the epicentres for coronavirus in India and to understand the rapid increase in COVID-19 cases, it is important to understand the phenomenon and responsible factors for its spreading. The available data corresponding to COVID-19 along with $\mathrm{T}\left({ }^{\circ} \mathrm{C}\right), \mathrm{RH}(\%)$, and PM, the analysis over DEL has been conducted. The results of 2-tailed Bivariate Pearson correlation (Table 1), were applied among Total Cases (TC), Active Case (AC), Recovered Case (RC), $\mathrm{PM}_{1.0}, \mathrm{PM}_{2.5}, \mathrm{PM}_{10}, \mathrm{~T}\left({ }^{\circ} \mathrm{C}\right)$, and $\mathrm{RH}$ (\%) over DEL for the period 1 April 2020 to 15 May 2020.

Based on forty-five days data for period $1^{\text {st }}$ April 2020 to $15^{\text {th }}$ April 2020, it was observed the average TC, AC, RC, DC as $3003 \pm 2393,2137 \pm 1514,821 \pm 877,44 \pm 28$ respectively. During this period the mean concentration of $\mathrm{PM}_{1.0}, \mathrm{PM}_{2.5}$, and $\mathrm{PM}_{10}$ were $31.42 \mu \mathrm{g} . \mathrm{m}^{-3}, 46.36 \mu \mathrm{g} . \mathrm{m}^{-3}$ and $50.78 \mu \mathrm{g} \cdot \mathrm{m}^{-3}$, respectively. However, the average $\mathrm{T}\left({ }^{\circ} \mathrm{C}\right)$ and $\mathrm{RH}(\%)$ were $34.72^{\circ} \mathrm{C}$ and $27.86 \%$ respectively. The Pearson correlation results (Table 1) over DEL revealed the considerable correlation of $\mathrm{T}\left({ }^{\circ} \mathrm{C}\right)$ with TC $(0.57, \mathrm{p}=0)$, AC $(0.59, \mathrm{p}=0), \mathrm{RC}(0.51, \mathrm{p}=0)$ and $\mathrm{DC}(0.58, \mathrm{p}=0)$ related to COVID-19 and clearly indicates the increase in total and active COVID-19 cases due to elevation of $\mathrm{T}\left({ }^{\circ} \mathrm{C}\right)$. Due to the unavailability of the data related to the other features

Table 1: Two-tailed Bivariate Pearson correlation among Total Cases (TC), Active Case (AC), Recovered Case (RC), $\mathrm{PM}_{1.0}, \mathrm{PM}_{2.5}, \mathrm{PM}_{10}, \mathrm{Temp}$ and RH over DEL. (** shows here that Correlation is significant at the 0.01 level (2-tailed) and * showing that Correlation is significant at the 0.05 level (2-tailed).

\begin{tabular}{|c|c|c|c|c|c|c|c|c|c|c|}
\hline \multicolumn{11}{|c|}{ 2-tailed bivariate Pearson correlation } \\
\hline \multirow{3}{*}{ TC } & & $\mathrm{TC}$ & $\mathrm{AC}$ & $\mathrm{RC}$ & DC & PM 1.0 & PM 2.5 & PM 10 & Temp & $\mathbf{R H}$ \\
\hline & Pearson Correlation & 1.00 & $0.99^{* *}$ & $0.98^{* *}$ & $0.93^{* *}$ & $0.34^{*}$ & 0.21 & 0.16 & $0.56^{* *}$ & 0.28 \\
\hline & p-value & & 0.00 & 0.00 & 0.00 & 0.02 & 0.16 & 0.29 & 0.00 & 0.06 \\
\hline \multirow[t]{2}{*}{$\mathrm{AC}$} & Pearson Correlation & $0.99^{* *}$ & 1.00 & $0.95^{* *}$ & $0.92^{* *}$ & $0.33^{*}$ & 0.20 & 0.15 & $0.58^{* *}$ & 0.25 \\
\hline & p-value & 0.00 & & 0.00 & 0.00 & 0.03 & 0.19 & 0.34 & 0.00 & 0.10 \\
\hline \multirow[t]{2}{*}{$\mathbf{R C}$} & Pearson Correlation & $0.98^{* *}$ & $0.95^{* *}$ & 1.00 & $0.92^{* *}$ & $0.36^{*}$ & 0.23 & 0.18 & $0.52^{* *}$ & $0.33^{*}$ \\
\hline & p-value & 0.00 & 0.00 & & 0.00 & 0.01 & 0.12 & 0.24 & 0.00 & 0.03 \\
\hline \multirow[t]{2}{*}{ DC } & Pearson Correlation & $0.93^{* *}$ & $0.92^{* *}$ & $0.92^{* *}$ & 1.00 & $0.32^{*}$ & 0.20 & 0.14 & $0.58^{* *}$ & 0.26 \\
\hline & p-value & 0.00 & 0.00 & 0.00 & & 0.03 & 0.20 & 0.37 & 0.00 & 0.08 \\
\hline \multirow[t]{2}{*}{ RH } & Pearson Correlation & 0.28 & 0.25 & $0.33^{*}$ & 0.26 & 0.09 & 0.06 & 0.03 & -0.07 & 1.00 \\
\hline & $\mathrm{p}$-value & 0.06 & 0.10 & 0.03 & 0.08 & 0.55 & 0.70 & 0.85 & 0.65 & \\
\hline
\end{tabular}


that contribute to affecting the rate of spread of COVID-19 infection within a DEL region, the analysis does not point out towards temperature as a single one factor responsible for the transmission of COVID-19. As the increase in the T $\left({ }^{\circ} \mathrm{C}\right)$ over DEL during April and May is also associated to the seasonal weather phenomenon, so it is difficult to declare the accurate association of $\mathrm{T}\left({ }^{\circ} \mathrm{C}\right)$ with the TC. The important finding related to the worthy positive correlation $(0.51, \mathrm{p}=$ $0)$ of $\mathrm{T}\left({ }^{\circ} \mathrm{C}\right)$ and $\mathrm{RC}$ has been observed but the probability of a significant increase in $\mathrm{RC}$ with temperature alone is not reasonable to come at some conclusion.

There is a relationship between $\mathrm{RH}(\%)$ and the COVID-19 virus persistence (Oliveiros et al. 2020 . Most viruses survive best at low $\mathrm{RH}(<40 \%)$ and extremely high $\mathrm{RH}$ $(>90 \%)$. But, the relationship between the survival of the COVID-19 virus and relative humidity needs to be explicated (Paul et al. 2020). Here, the RH (\%) shows the least correlation with TC $(0.28, \mathrm{p}=0.06)$, AC $(0.25, \mathrm{p}=0.10)$, and DC $(0.26, p=0.08)$ and moderate correlation with RC $(0.33, p=0.03)$. Such a good correlation of RH (\%) with $\mathrm{RC}$ suggests the slight positive influence of RH on RC. The lower humidity supports the aerosol particles to reduce its size to stay suspended in the air for a longer time. As in the existing months (April to May 2020), the mean RH (\%) is lower $(27.86 \%)$ and the infection spread may be due to the suspended aerosol particles. In the case of COVID-19 virus dissemination, these suspended aerosols particles may play a major role in the transmission of the virus from one to another but up to some inadequate distance. To avoid this infection, the Government of India, declared the guidelines to maintain the social distancing as a well minimum of 1-meter distance with another person which was helpful to avoid the possibility of infection and a large increase in the number of $\mathrm{TC}(0.28, \mathrm{p}=0.06)$.

The increase of $\mathrm{RH}(\%)$ with the presence of droplets in the atmosphere supports the heavy aerosol particles to settle down on the ground surface. So, in this case, when the infected person, coughs or sneezes in an open area, the aerosol droplets due to its heaviness starts to settle down on the surface and further contribute to transmitting the COVID-19 virus through the surface contact.

Some earlier studies found the significant role of $\mathrm{T}\left({ }^{\circ} \mathrm{C}\right)$ and $\mathrm{RH}(\%)$ responsible for the spread of many respiratory infectious diseases like influenza (Barreca et al. 2012, Lowen et al. 2007). Chen et al. (2020), reported that the cities with the prevalent transmission of COVID-19 virus were with high $\mathrm{RH}$ of $60-90 \%$ and low $\mathrm{T}\left({ }^{\circ} \mathrm{C}\right)$. To diagnose the influence of the concentration of particulate pollutants on the total number of COVID-19 cases, the spatio-temporal analysis (Fig. 7) was done.

It was found that there was 154 number of confirmed cases of COVID-19 on dated 1 April 2020 which corresponds to the particulate mass concentration of $21.96 \mu \mathrm{g} \cdot \mathrm{m}^{-3}\left(\mathrm{PM}_{1.0}\right)$, $34.69 \mu \mathrm{g} \cdot \mathrm{m}^{-3}\left(\mathrm{PM}_{2.5}\right)$ and $39.04 \mu \mathrm{g} \cdot \mathrm{m}^{-3}\left(\mathrm{PM}_{10}\right)$. After 43 days $\left(15^{\text {th }}\right.$ May 2020), the cases of COVID-19 in DEL reached up to a maximum number of 8470 with the increase of $98.02 \%$, and in the similar pattern the PM concentration also rapidly increased by $48 \%\left(\mathrm{PM}_{1.0}\right), 40.47 \%\left(\mathrm{PM}_{2.5}\right)$ and $38.02 \%$ $\left(\mathrm{PM}_{10}\right)$. The increase in the number of COVID-19 cases with the increase of particulate matter mass concentration over DEL suggests the influence of fine and coarse particulate matter on TC. The influence of variable sizes of PM on TC, AC, RC and DC were demonstrated using the Pearson correlation (r) and Sig. 2-tailed, i.e. p-values.

The PM of different sizes, i.e. $\mathrm{PM}_{1.0}, \mathrm{PM}_{2.5}$ and $\mathrm{PM}_{10}$ demonstrated the correlation ( $r$ ) with TC, AC, RC and DC (Table 1). The $\mathrm{PM}_{1.0}$ has the moderate correlation with TC (0.34, p = 0.02), AC (0.33, p = 0.02), RC (0.36, p = 0.01) and DC $(0.32, \mathrm{p}=0.02)$ whereas $\mathrm{PM}_{2.5}$ and $\mathrm{PM}_{10}$ had least correlation value (r) with TC, AC, RC and DC as $0.21(\mathrm{p}=$ $0.15), 0.19(\mathrm{p}=0.19), 0.23(\mathrm{p}=0.12), 0.19(\mathrm{p}=0.19)$ and $0.16(\mathrm{p}=0.29), 0.14(\mathrm{p}=0.23), 0.18(\mathrm{p}=0.23)$ and $0.13(\mathrm{p}$ $=0.36)$, respectively. Our studies indicate that $\mathrm{PM}_{1.0}$ is relatively more associated with the various stages of COVID-19

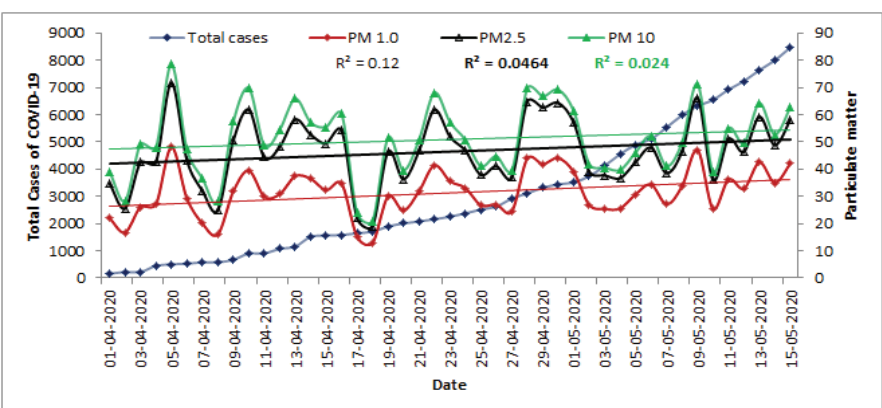

Fig. 7: Spatio-temporal observation between fine $\left(\mathrm{PM}_{1.0}, \mathrm{PM}_{2.5}\right)$ and coarse $\left(\mathrm{PM}_{10}\right)$ particulate pollutants and TC of COVID-19. 
patients, i.e. TC, $\mathrm{AC}, \mathrm{RC}$ and $\mathrm{DC}$ as compared to $\mathrm{PM}_{2.5}$ and $\mathrm{PM}_{10}$. These findings suggest that, while direct COVID-19 infection is vital track of transmission, the role of $\mathrm{PM}_{1.0}$ in virus transmission may play a significant character. The $\mathrm{RH}$ (\%) was associated with the PM by signifying the correlation (r) as follows, i.e. $0.09\left(\mathrm{PM}_{1.0}\right), 0.05\left(\mathrm{PM}_{2.5}\right)$ and $0.03\left(\mathrm{PM}_{10}\right)$. Also the Sig. (2-tailed), i.e. p values of 0.54, 0.69 and 0.84 related to $\mathrm{PM}_{1.0}, \mathrm{PM}_{2.5}$ and $\mathrm{PM}_{10}$ respectively, demonstrate the extremely less influence of RH (\%) on PM over DEL during the study period.

\section{CONCLUSION}

The paper validates the effect of lockdown over Delhi and Gurgaon on the particulate matter in air. This is the first study that attempts to demonstrate the effects of meteorological factors in COVID-19 in DEL. It has been observed that prominent effect of lockdown demonstrates the decline of $67.31 \%$, $70.29 \%$ and $71.66 \%$ over Delhi and $48.21 \%, 51.82 \%$, and $52.45 \%$ over Gurgaon in $\mathrm{PM}_{1.0}, \mathrm{PM}_{2.5}$, and $\mathrm{PM}_{10}$, respectively. In this study, the particulate matter, temperature and relative humidity justify special attention. Relative humidity (RH \%) was found as a substantial parameter that showed a significant correlation with COVID 19 recovered cases. For the study period selected, the COVID-19 recovered cases in Delhi were observed to be favoured by lower mean relative humidity $\left(27.86^{\circ} \mathrm{C}\right)$ that was validated through the moderate correlation of $0.33(p=0.03)$ with the recovered cases. Such correlation suggests the influence of relative humidity on COVID-19 recovered cases. Based on the dual character of $\mathrm{RH}(\%)$ on the dispersion of COVID-19 virus, the increase in the number of COVID-19 cases in July and August through surface transmission can be predicted.

However, it is essential to declare that the present study presents a preliminary investigation and as per our observation, an extensive study with long term data might enhance the understanding between meteorological conditions and the COVID-19 transmissibility.

\section{ACKNOWLEDGEMENT}

We thank to PurpleAir for particulate pollutants data and New Delhi Television Limited (NDTV) for providing the COVID-19 updated. We are also thankful to the Editor of NEPT and two unknown referees for their valuable suggestions to improve the manuscript.

\section{ABBREVIATIONS}

$\begin{array}{llll}\text { COVID-19 } & \text { Coronavirus } & \text { SP } & \text { Shantipath } \\ \text { DEL } & \text { Delhi } & \text { GK } & \text { Greater Kailash }\end{array}$

$\begin{array}{llll}\text { GW } & \text { Gurgaon } & \text { LR } & \begin{array}{l}\text { Lodhi Road } \\ \text { PM }\end{array} \\ \text { Particulate matter } & \text { WHO } & \begin{array}{l}\text { World Health Organi- } \\ \text { zation }\end{array} \\ \text { T } & \text { Temperature } & \text { TC } & \text { Total cases } \\ \text { RH } & \text { Relative Humidity } & \text { RC } & \text { Recovered cases } \\ \text { IIT-DEL } & \text { IIT-Delhi } & \text { AC } & \text { Active cases } \\ \text { USE } & \text { US Embassy } & \text { DC } & \text { Death cases } \\ \text { MGS } & \text { Mahant-Gurmukh } & \text { NAAQS } & \begin{array}{l}\text { National Ambient Air } \\ \text { Quality Standards }\end{array} \\ & \text { Singh } & & \end{array}$

\section{REFERENCES}

Anderson, J.O., Thundiyil, J.G. and Stolbach, A. 2012. Clearing the air: A review of the effects of particulate matter air pollution on human health. J. Med. Toxicol., 8(2): 166175.

Arif, M., Kumar, R., Kumar, R., Eric, Z. and Gourav, P. 2018. Ambient black carbon, PM2.5 and PM10 at Patna: Influence of anthropogenic emissions and brick kilns. The Science of the Total Environment, 624: 1387-1400.

Aggarwal, P. and Jain, S. 2015. Impact of air pollutants from surface transport sources on human health: A modeling and epidemiological approach. Environ. Int., 83: 146-157. https://doi.org/10.1016/j. envint.2015.06.010.

Barreca, A.I. and Shimshack, J.P. 2012. Absolute humidity, temperature, and influenza mortality: 30 years of county-level evidence from the United States. American Journal of Epidemiology, 176(7): 114 - 122.

Bhaskar, B.V. and Mehta, V.M. 2010. Atmospheric particulate pollutants and their relationship with meteorology in Ahmedabad. Aerosol Air Qual. Res., 10: 301-315.

Bao, R. and Zhang, A. 2020. Does lockdown reduce air pollution? Evidence from 44 cities in northern China. Sci. Total Environ., 731: 139052. https://doi.org/10.1016/j.sci totenv.2020.139052.

Cohen, A.J., Anderson, H.R., Ostra, B., Pandey, K.D., Krzyznowski, M., Gutschmidt, N.K.K., Pope, A., Romieu, I., Samet, R.J.M. and Smith, K. 2005.The global burden of disease due to outdoor air pollution. J. Toxicol. Environ. Health A, 68: 1-7.

Chen, C. and Zhao, B. 2020. Makeshift hospitals for COVID-19 patients: Where health-care workers and patients need sufficient ventilation for more protection. J. Hosp. Infect. https://doi.org/10.1016/j. ihin.2020.03.008.

Chauhan A. and Singh R.P. 2020. Decline in $\mathrm{PM}_{25}$ concentrations over major cities around the world associated with COVID-19. Environmental Research, 2020: 187.

Down to Earth (https://www.downtoearth.org.in/)

Daoru, L., Deng, Q., Zhou, Z., Lin, Y. and Tao, J. 2018.Variation trends of fine particulate matter concentration in Wuhan City from 2013 to 2017. Int. J. Environ. Res. Public Health, 15 (7): 1487.

Dockery, D., Pope, C., Xu, X., Spengler, J., Ware, J., Fay, M., Ferris, B. and Speizer, F. 1993. An association between air pollution and mortality in six U.S. cities. N. Engl. J. Med., 329: 1753-1759.

Donaldson, K., Stone, V., Seaton, A. and MacNee, W. 2001. Ambient particle inhalation and the cardiovascular system: potential mechanisms. Environ. Health Persp., 109: 523-527.

Donnelly, C.A., Ghani, A.C., Leung, G.M., Hedley, A.J., Fraser, C., Riley, S., Radded, L.A.J., Ho, L.M., Thach, T.Q., Chau, P., Chan, K.P., Lam, T.H., Tse, L.Y., Tsang, T., Liu, S.H., Kong, J.H.B., Lau, E.M.C., Ferguson, N.M. and Anderson, R.M. 2003. Epidemiological determinants of spread of causal agent of severe acute respiratory syndrome in Hong Kong. Lancet, 361(9371): 1761-1766.

Espinosa, A.J.F., Rodriguez, M.T. and Alvarez, F.F. 2004. Source charac- 
terisation of fine urban particles by multivariate analysis of trace metal speciation. Atmos. Environ., 38: 873 - 886.

Gulia, S., Mittal, A. and Khare, M. 2018. Quantitative evaluation of source interventions for urban air quality improvement- A case study of Delhi city. Atmos. Pollut. Res., 9: 577-583.

Guttikunda, S.K. and Calori, G. 2013. A GIS based emissions inventory at $1 \mathrm{~km} \times 1 \mathrm{~km}$ spatial resolution for air pollution analysis in Delhi, India. Atmos. Environ., 67: 101-111.

Goyal, P. 2003. Present scenario of air quality in Delhi: A case study of CNG implementation. Atmospheric Environment, 37: 5423-5431.

Hales, S., Blakely, T. and Woodward, A. 2010. Air pollution and mortality in New Zealand: Cohort study. J. Epidemiol. Community Health, 66: 468-473.

Jain, S. and Sharma, T. 2020. Social and travel lockdown impact considering coronavirus disease (COVID-19) on air quality in megacities of India: Present benefits, future challenges and ways forward. Aerosol Air Qual. Res., 20: 1222-1236.

Karar, K. and Gupta, A.K. 2006. Seasonal variations and chemical characterization of ambient $\mathrm{PM}_{10}$ at residential and industrial sites of an urban region of Kolkata (Calcutta), India. Atmos. Res., 81: 36-53.

Kumar, P., Gulia, S., Harrison, R.M. and Khare, M. 2017. The influence of odd-even car trial on fine and coarse particles in Delhi. Environ. Pollut., 225: 20-30.

Kumar, P., Jain, S., Gurjar, B.R., Sharma, P., Khare, M., Morawska, L. and Britter, R. 2013. New Directions: Can a "blue sky" return to Indian megacities? Atmos. Environ., 71: 198-201. https://doi.org/10.1016/j. atmosenv.2013.01.055.

Lowen, A.C., Mubareka, S., Steel, J. and Palese, P. 2007. Influenza virus transmission is dependent on relative humidity and temperature. PLoS Pathogens, 3(10): 1470-1406.

Ministry of Health and Family Welfare, Government of India (https://www. mohfw.gov.in/).

Oliveiros, B., Caramelo, L., Ferreira, N.C. and Caramelo, F. 2020. Role of temperature and humidity in the modulation of the doubling time of COVID-19 cases. Preprint at Med RXIV, doi.org/10.1101/2020.0 3.05.20031872.
Paul J. Villeneuve and Mark S. Goldberg. 2020. Methodological considerations for epidemiological studies of air pollution and the SARS and COVID-19 coronavirus outbreaks. Environmental Health Perspectives, 128(9): 095001.

Saksena, S. and Dayal, V. 2000. Total exposure as a basis for the economic valuation of air pollution in India. Energy Environment Monitor, 13(2): 93-102.

Susanta Mahato, Swades Pal and Krishna Gopal Ghosh 2020. Effect of lockdown amid COVID-19 pandemic on air quality of themegacity Delhi, India. Science of the Total Environment, 730: 139086.

Sahu, S.K., Beig, G. and Parkhi, N.S. 2011. Emissions inventory of anthropogenic PM2.5 and PM10 in Delhi during commonwealth games 2010. Atmospheric Environment, 45: 6180-6190.

Singh, D.P., Gadi, R. and Mandal, T.K. 2011. Characterization of particulate-bound polycyclic aromatic hydrocarbons and trace metals composition of urban air in Delhi, India. Atmos. Environ., 45: 7653-7663.

Tiwari, S., Bisht, D.S., Srivastava, A.K., Pipal, AS., Taneja, A., Srivastava, M.K. and Attri, S.D. 2014.Variability in atmospheric particulates and meteorological effects on their mass concentrations over Delhi, India. Atmos. Res., 45(46): 145-146.

Xu, K., Cui, K., Young, L.H., Hsieh, Y.K., Wang, Y.F., Zhang, J. and Wan, S. 2020. Impact of the COVID-19 event on air quality in central China. Aerosol Air Qual. Res., 20: 915-929. https://doi.org/10.4209/ aaqr.2020.04.0150.

Wang, P., Chen, K., Zhu, S., Wang, P. and Zhang, H. 2020. Severe air pollution events not avoided by reduced anthropogenic activities during COVID-19 outbreak. Resour. Conserv. Recycl., 158: 104814. https:// doi.org/10. 1016/j.resconrec.2020.104814.

Wu, X., Nethery, R.C., Sabath, B.M., Braun, D. and Dominici, F. 2020. Exposure to air pollution and COVID-19 mortality in the United States. medRxiv 2020.04.05.20054502. https://doi.org/10.1101/2020 .04 .05 .20054502 .

World Health Statistics 2018. Monitoring health for the SDGs (https://www. who.int/gho/publications/world health statistics/2018/en/).

WHO 2020. Coronavirus disease (COVID-19) pandemic (www.who.int/ emergencies/diseases/novel-coronavirus). 